\title{
Android Smartphone Among Young People
}

\author{
Daryono Setiadi ${ }^{{ }^{*}}$, Nurjanah Rahayuningsih ${ }^{1}$, Surianti ${ }^{1}$ and Samsul Anwar ${ }^{1}$ \\ 1 Universitas Wiralodra, Indramayu, West Java, Indonesia \\ daryono.fe@gmail.com \\ ${ }^{*}$ Corresponding Author
}

How to Cite : Setiadi, D., Rahayuningsih, N., Surianti, S., Anwar, S. (2019). Android Smartphone Among Young People. International Journal for Educational and Vocational Studies, 1 (5), 514-518

\section{ARTICLE HISTORY}

Received: 6 July 2019

Revised: 27 July 2019

Accepted: 20 August 2019

\section{KEYWORDS}

Price Perception;

Product Features;

Word of Mouth;

Purchase Decision;

\begin{abstract}
This study aims to determine purchasing decisions among young people who need their daily life is still filled by the lord yes. Android smartphones among young people are still included in the category of expensive items. The sample used is young people who are still learning and have no income. Consumers in determining the decision to purchase products are influenced by including price perceptions, product features, and word of mouth. Consumer complaints about price perceptions are caused by Android smartphones perceived to be more expensive. Price perception is related to how price information is understood entirely by consumers and gives a deep meaning to them, three indicators namely: Price conformity to product quality, Price conformity to benefits and Competitive prices. Product features are elements of a product that are considered important by consumers and are used as the basis for making a purchasing decision, researchers use four indicators, namely: Diversity of Features, Quality of Features, Importance of Features and Completeness of Features. Word of Mouth or WOM is the act of providing any information related to the product by consumers to other consumers. there are three indicators of Word of Mouth, namely: Word of Mouth Organic, Word of Mouth Amplified and Word of Mouth Marketing. The purchase decision is a decision as the choice of an action of two or more alternative choices, there are six indicators namely: Product choice, Brand choice, Time choice, Store choice, Choice of amount and Choice of payment. From the results of this study it was found that the influence of Price Perception $\left(X_{1}\right)$, Product Features $\left(X_{2}\right)$ and Word of Mouth $\left(X_{3}\right)$ on Purchasing Decisions $(Y)$ had a very strong and positive effect because when young people whose financial needs were still met from his parents or young people who have not worked is largely determined by the variable Price Perception $\left(X_{1}\right)$, Product Features $\left(X_{2}\right)$ and Word of Mouth $\left(X_{3}\right)$ together or simultaneously affect the Purchase Decision $(Y)$ of an android smartphone.
\end{abstract}

This is an open access article under the CC-BY-SA license.

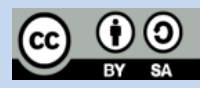

\section{INTRODUCTION}

Young people of the population on a small scale, but have a very large contribution. Important to understand the past teenagers because teenagers are the future front of every society. The period of adolescence is a phase of development of the future child-a child and a grown-up, takes place between the ages of 12-24 years (WHO, 2010). WHO said that, when it is estimated $27-31 \%$ of the population worldwide aged between $10-24$ than and $83 \%$ of them are located in countries that were developing (Dhamayanti, 2009).

In the younger generation is not the one thing that is new in children adolescents have gadgets such as smartphones and computer tablets such as ios and windows and android. When this gadget among adolescents are not only used as a medium of communication only, gadgets among teens already becoming a tool multi function. Camera one of them can be used by users of gadgets to capture the moment the mome- nt his own, in addition to the facility of social media is also becoming southwest attraction of its own for the teens to socialize atupun show the creativity that they have.

Almost all children adolescents already have gadgets. Students who have gadgets always bring their gadgets to school. Not infrequently they use gadgets during school hours. Benefits of the gadget itself assortment to calculate , access the Internet, send messages, play games, and networking social open like facebook or twitter is often done when the process of learning that was taking place. Signs of a teenager already addicted to gadgets that use of the gadget in a day can be more than 6-8 hours even more inside, the impact of another can change the behavior of the child into the individualism that is more happy to play with the phone rather than playing with the environment around. Gadgets addiction can also have an impact on health that makes physical activity begin to decline so as to minimize movement, and even tend not to move when holding a cell phone. 
According to the statistics institute research marketing digital estimate of e-marketers in 2018 the number of users active smartphones in Indonesia more than 100 million people. With that amount, Indonesia will be the country with the smartphone 's largest four are active in the world after China, India, and America. Indonesia is not much different from India. Internet penetration in Indonesia in 2014, according to live internet statistics, is in the range of $17 \%$ and the percentage of Indonesians making new online purchases is around $16 \%$.

Factors that could potentially increase the likelihood someone consumer to buy a product, which is associated with the evaluation of the quality of the product, price, brand, uniqueness of products from in terms of design and color as well as the services that are given (Stanton, 1996). The decision of purchase is the activities of individuals who are directly involved in making the decision to carry out the purchase of the product that is offered by the seller. Purchasing decisions are the stages in the decision making process of buyers where consumers actually buy (Kotler and Armstrong,2001). Smartphones (phones smart) is a telephone cell which has the ability to use and functions that resemble computer. There are no factory standards that determine the meaning of a smartphone. For some people, a smartphone is a phone that works using the device software system of operation that provides relations standards and fundamental for developers of applications.

According to Monroe (2005) the price of the sacrifice economical that made customers to acquire products or services. Besides that, price is one of the important factors for consumers in making a decision whether or not to make a transaction (Sukotjo and Radix, 2010). Price perception is related to how price information is understood entirely by consumers and gives a deep meaning to them (Peter and Olson, 2000). Research that is done by Aditya Yessika Alana, Wahyu Hidayat, and Handoyo Djoko W (2012) indicates that the price impact positively and significantly to the decision of purchase . However, studies are carried out by Muhammad Lutfi Khakim (2015) showed that the price effect is positive but not significant to the decision of purchase. The price of Android smartphones, the majority of which do not match their quality, is a consumer complaint.

Features are characteristics that may be owned or not owned by the object (Kotler and Armstrong, 2006). Various products are similar may be viewed differently by consumers of comparison of features in it, namely comparison completeness of features, sophistication of feature or feature that is highlighted on the features in a product compared with the products of others. Features are elements of a product that are considered important by consumers and are used as the basis for making a purchasing decision ( Fandy Tjiptono, 2002). Muhammad Ichsan, Maria Magdalena Minarsih, Leonardo Budi Hasiholan (2015) revealed that the features had a significant effect on purchasing decisions. Android is an OS (Operating System) that is installed on several different devices.

Consumers usually can find out a product that is new on the ad or power seller. But most plays is the word of mouth that develops in between the consumer 's own. Promotion through mouth to mouth were done by friends or relatives and even others as netizens have credibility high, so more is persuasive than promotion through advertising.Because consumers more trust others more used to try a product rather than an ad.

Based on the above background that the decision to buy an android smartphone according to some researchers is influenced by price perceptions, product features and word of mouth. But if the variables that will affect if the purchaser children young who need to live day-to-day still in the fill of the parents?

\section{METHODS}

\subsection{Price Perception}

Price perception is related to how price information is understood entirely by consumers and gives a deep meaning to them (Pater and Olson, 2000). Price perception is something that is sacrificed by consumers to get a product (Zeithmal, 1988). Often some consumers to know is the exact price of a product, while the others only able to estimate the price based on the purchase of future past. While the Sweeney, Soutar and Johnson (2001) explains that factors such as quality, response to emotional, price and status of social is the dimension of perceived value. Quality is seen from several aspects of the product are made, while emotional responses are more related to consumer feelings after buying a product . In buying a product consumers not only consider the quality of course, but also to think about the feasibility of costs ( Sweeney, et.al, 2001).

To measure the variable perception of price, according Tjiptono, Chandra and Adriana (2008) there are three indicators namely : Kesesuaia $\mathrm{n}$ price with quality product, price compatibility with the benefits and price competitive.

\subsection{Product Features}

Features are characteristics that complement the basic functions of a product (Kotler and Keller, 2012). Efforts to become the first to introduce distinctive new that is worthwhile is one of one of the ways that effective to compete. And according to Tjiptono (2002) Features are elements of a product that are considered important by consumers and serve as the basis for making a purchasing decision ( Tjiptono, 2002).

To measure the variable features of the product, according to Kotler and Keller (2012) there are four indicators are: The diversity of features, quality features, Interests Features and Fittings Features. 


\subsection{Word of Mouth}

WOMMA (Word of Mouth Marketing Association) is an activity in which consumers provide information about a brand or product to other consumers. Word of Mouth Marketing is a marketing activity that triggers consumers to discuss, promote, recommend to sell the brand of a product to other potential customers (Sumardi et al ., 2011).

Companies can encourage and facilitate a conversation from mouth to mouth that the first advance to make sure that the product or the brand of the company is unique, innovative and should be a conversation product that creates WOM are positive that in the end will result in sales for the company (Yosevina, 2008). To measure word of mouth variables, according to Sumardi et al . (2011) there are three indicators, namely: Word Of Mouth Organic, Word Of Mouth Amplified and Word Of Mouth Marketing.

\subsection{Purchase Decision}

The decision of purchase is making the decision the consumer is a process of integration that combines the knowledge to evaluate two or more behavioral alternatives and choose one of them (Setiadi, 2003). Same as the diselaskan by Sumarwan (2004) purchase is a decision as selecting an action of two or more choice alternative.

Decision purchases by Schiffman Kanuk (2004: 547) in Hatane Samuel (2007: 75) is the selection of two or more alternative choice decision of purchase, meaning that a person can make a decision, should be available some alternative choice. The decision to purchase can lead to how the process in making the decision that was made. Purchasing decisions, according to Kotler \& Armstrong (2001: 226) in Ghazali (2010: 26) are the stages in the process of purchasing decisions in which consumers actually buy.

To measure the variables decision of purchase , according to Kotler (2000) there are six indicators, namely : Featured products, Featured brands, Options time, options took, Option number and 6. Option means of payment.

\subsection{Effect of Price Perception on Purchasing Decisions}

Perception prices often become the target of investigation in a research compared with objective price, consumers express the price of the product as a price that is inexpensive, entry reasonable (reasonably), or expensive based on internal reference price them (Zeithaml, 1988). Perception prices are cheap and affordable will affect the decision of buying an Android smartphone.

\subsection{Effect of Product Features on Purchasing Decisions}

Power -resistant battery, dual sim card, the speed of the processor, the clarity of the screen, camera, near field communications, multitasking, space storage additional (external), and remote infrared is a feature of Android smartphones that will greatly influence the decision of buying consumers .

\subsection{Effect of Word of Mouth on Purchasing Decisions}

Reviews of netizens and the nearby consumers who already use Android smartphone will influence the decision of buying an Android smartphone that.

\subsection{Effect of Perception, Product Features, And Woerd of Mounth on Purchasing Decisions}

How consumers perceive prices are subject to what are perceived consumer, if the features of a product that felt good then consumers consider the price of the actual height be commensurate with what are acceptable and so also vice versa. Then if consumers feel satisfied with the features of the product and the price of Android smartphones are appropriate, then they will become agents of word of mouth that will stimulate the decision of purchase of the product.

\subsection{Research Hypothesis}

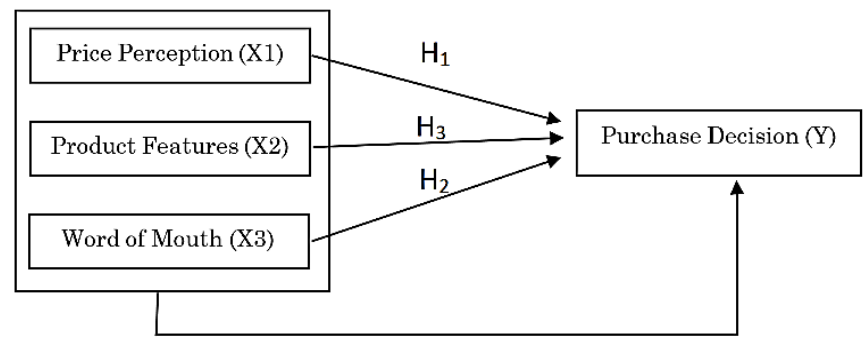

Figure 1. Research Hypothesis

\subsection{Statistical Data Analysis}

The method of research that is used is the method descriptive and associative, methods of descriptive a method of study that provides an overview and reveals a problem that occurred at the time the study took place, while the method of associative to determine the relationship between two variables or more in a sample that will be tested. Variable-free (independent variable) in research this is the perception of price $\left(\mathrm{X}_{1}\right)$, features $\left(\mathrm{X}_{2}\right)$, and word of mouth $\left(\mathrm{X}_{3}\right)$. While variable dependent (dependent variable) in research this is the decision of purchase of the consumer (Y). The survey method was chosen as the primary data source obtained through a questionnaire. Survey research is data collection using questionnaire/interview instruments to get responses from respondents (Sugiyono, 2013). Methods survey conducted for the cost of research which are relatively low and can be done in a time that is relatively short .

The samples in the study 's 203 respondents, they all need life was filled from the parent them or they have not worked and aged 19-24 years . 


\section{RESULTS AND DISCUSSION}

The samples in the study is 203 respondents and they were all the needs of life is still filled from the parent them or they have not worked and aged 19-24 years .

\subsection{Descriptive Analysis}

Mean, Median, Mode and Standard Deviation of each research variable:

Table 1. Mean, Median, Mode and Standard Deviation of Variables

\begin{tabular}{lcccc}
\hline & $\mathrm{X}_{1}$ & $\mathrm{X}_{2}$ & $\mathrm{X}_{3}$ & $\mathrm{Y}$ \\
\hline Mean & 28.5 & 32 & 17.2 & 25.3 \\
\hline Media & 28 & 32 & 17 & 25 \\
\hline Mode & 27 & 32 & 15 & 23 \\
\hline $\begin{array}{l}\text { Standard } \\
\text { Deviation }\end{array}$ & 3.571 & 4,5915 & 3.392 & 4,072 \\
\hline Variant & 12.754 & 21.082 & 21.082 & 16,585 \\
\hline
\end{tabular}

Sources: Primary data that have been in if using Ms.Excel 2016

Table 2. Normality Test Results

One-Sample Kolmogorov-Smirnov Test

\begin{tabular}{|c|c|c|c|c|c|}
\hline & & $X_{1}$ & $X_{2}$ & $X_{3}$ & $\mathrm{Y}$ \\
\hline $\mathrm{N}$ & & 203 & 203 & 203 & 203 \\
\hline \multirow{2}{*}{$\begin{array}{l}\text { Normal Parameters a, } \\
b\end{array}$} & Mean & 28.5 & 28.5 & 28.5 & 28.5 \\
\hline & Std. Deviation & 3,571 & 3,571 & 3,571 & 3,571 \\
\hline \multirow{3}{*}{$\begin{array}{ll}\text { Most } & \text { Extreme } \\
\text { Differences } & \end{array}$} & Absolute &, 090 &, 097 &, 089 &, 095 \\
\hline & Positive &, 090 &, 072 &, 078 &, 089 \\
\hline & Negative & $-0,76$ & $-0,76$ & $\begin{array}{r}- \\
0,76 \\
\end{array}$ & $-0,76$ \\
\hline \multicolumn{2}{|l|}{ Statistical Test } & 1,085 & 1,097 &, 985 & 1,005 \\
\hline \multicolumn{2}{|l|}{ Asymp. Sig. (2-tailed) } &, 211 &, 221 &, 244 &, 292 \\
\hline
\end{tabular}

Source: Primary Data 2019 (SPSS 14.00)

Based on the results of the normality test above it can be concluded that the research data of each variable is normally distributed because it has a significance value greater than 0.05 .

\subsection{Associative Analysis}

Table 3. Correlation Test Results

\begin{tabular}{cc}
\hline & Correlation \\
\hline$X_{1}->Y$ & 0.333104 \\
\hline$X_{2}->Y$ & 0.246146 \\
\hline$X_{3}->Y$ & 0.249855 \\
\hline$X_{1}, X_{2}, X_{3}->Y$ & 0.975133 \\
\hline
\end{tabular}

Source: Primary data processing

1. Effect of Price Perception $\left(\mathrm{X}_{1}\right)$ on Purchasing Decisions (Y)
Based on the table above, the correlation between price perception of purchasing decisions is obtained with a value of 0.333 , which means low and positive (unidirectional) effect.

2. Effect of Product Features $\left(\mathrm{X}_{2}\right)$ on Purchasing Decisions (Y)

Based on the table above the correlation between Product Features on purchasing decisions obtained with a value of 0.246 means that the effect is low and positive (unidirectional).

3. Effect of Word of Mouth $\left(\mathrm{X}_{3}\right)$ on purchase decisions (Y)

Based on the table above the correlation between Word of Mouth on purchasing decisions obtained with a value of 0.250 means that the effect is low and positive (unidirectional).

4. Effect of Price Perception $\left(\mathrm{X}_{1}\right)$, Product Features $\left(\mathrm{X}_{2}\right)$ and Word of Mouth $\left(\mathrm{X}_{3}\right)$ on purchasing decisions (Y)

Based on the table above the correlation between Price Perception $\left(\mathrm{X}_{1}\right)$, Product Features $\left(\mathrm{X}_{2}\right)$ and Word of Mouth $\left(\mathrm{X}_{3}\right)$ to the purchase decision obtained with a value of 0,975 means that the effect is very strong and positive (unidirectional).

\subsection{Determine coefficientn}

The formula for the determinant coefficient is:

$$
\mathrm{Kd}=\mathrm{r}^{2} \times 100 \%
$$

Its function is to measure how much the contribution of independent variables to the dependent variable.

1. Determinant coefficient Price Perception $\left(\mathrm{X}_{1}\right)$ Against Purchasing Decisions (Y) obtained a value of $11 \%$, meaning that the influence of price perception affects $11 \%$ while $89 \%$ is influenced by other factors.

2. Determinant coefficient of Product Features $\left(\mathrm{X}_{2}\right)$ on Purchasing Decisions (Y) obtained a value of $6 \%$, meaning that the influence of Product Features affects $6 \%$ while $94 \%$ is influenced by other factors.

3. Word of Mouth's determinant coefficient $\left(\mathrm{X}_{3}\right)$ on Purchasing Decisions (Y) obtained a value of $6 \%$, meaning that the influence of Word of Mouth affects $6 \%$ while $94 \%$ is influenced by other factors.

4. Determinant coefficient Price Perception $\left(\mathrm{X}_{1}\right)$, Product Features $\left(\mathrm{X}_{2}\right)$ and Word of Mouth $\left(\mathrm{X}_{3}\right)$ Against Purchase Decision (Y) obtained a value of $95 \%$, meaning that the influence of Price Perception $\left(\mathrm{X}_{1}\right)$, Product Features $\left(\mathrm{X}_{2}\right)$ and Word of Mouth $\left(\mathrm{X}_{3}\right)$ affects $95 \%$ while $5 \%$ are influenced by other factors.

Base on results of this study it was found that the influence of Price Perception $\left(\mathrm{X}_{1}\right)$, Product Features $\left(\mathrm{X}_{2}\right)$ and Word of Mouth $\left(\mathrm{X}_{3}\right)$ on Purchasing Decisions (Y) had a very strong and positive effect because when young people whose financial needs were still met from his parents or young people who have not worked is largely determined by the variable Price Perception $\left(\mathrm{X}_{1}\right)$, Product Features 
$\left(\mathrm{X}_{2}\right)$ and Word of Mouth $\left(\mathrm{X}_{3}\right)$ together or simultaneously affect the Purchase Decision (Y) of an android smartphone.

\section{CONCLUSION}

Price perception $\left(\mathrm{X}_{1}\right)$ has a positive effect on purchasing decisions. This is evidenced by the regression coefficient of 0,333 with a significance value of 0,000 . Perception of price $\left(\mathrm{X}_{1}\right)$ has a positive effect indicating every increase in the value of the price perception variable $\left(\mathrm{X}_{1}\right)$, then

the purchase decision (Y) will also increase, but if the perceived price $\left(\mathrm{X}_{1}\right)$ decreases, the value of the purchase decision $(\mathrm{Y})$ will follow.

Product features $\left(\mathrm{X}_{2}\right)$ have a positive effect on purchasing decisions. This is evidenced by the regression coefficient of 0.246 with a significance value of 0,000 . Product features $\left(\mathrm{X}_{2}\right)$ have a positive effect indicating any increase in the value of product feature variables $\left(\mathrm{X}_{2}\right)$, then the purchase decision $(\mathrm{Y})$ will also increase, but if the product feature $\left(\mathrm{X}_{2}\right)$ decreases, the value of the purchase decision $(\mathrm{Y})$ will follow.

Word of mouth $\left(\mathrm{X}_{3}\right)$ has a positive effect on purchasing decisions. This is evidenced by the regression coefficient of 0,249 with a significance value of 0,000 . Word of mouth $\left(\mathrm{X}_{3}\right)$ has a positive effect indicating every increase in the value of the word of mouth variable $\left(\mathrm{X}_{3}\right)$, then the purchase decision (Y) will also increase, but if word of mouth $\left(\mathrm{X}_{3}\right)$ decreases, the value of the purchase decision (Y) will follow.

Price perception $\left(\mathrm{X}_{1}\right)$, product features $\left(\mathrm{X}_{2}\right)$, and word of mouth $\left(\mathrm{X}_{3}\right)$ together have a positive effect on purchasing decisions. So it is known that if the price perception variable $\left(\mathrm{X}_{1}\right)$, product features $\left(\mathrm{X}_{2}\right)$, and word of mouth $\left(\mathrm{X}_{3}\right)$ rise in one unit, then the purchase decision variable (Y) will be fulfilled. This is evidenced by the regression coefficient of 0,975 with a significance value of 0,000 .

\section{REFERENCES}

Hair, Joseph F. et all. (2010). Multivariate Data Analysis A Global Perspective. Seventh Edition. New Jersey: Pearson Education.

Juwita, Lewisa Nora. (2014). Pengaruh Kualitas Pelayanan, Suasana Toko, dan Word Of Mouth Terhadap Minat Beli Ulang Konsumen (Studi Pada Konsumen Waroeng Spesial Sambal). Universitas Negeri Yogyakarta.

Kasali, Rhenald. (2005). Sembilan Fenomena Bisnis. Jakarta: PT. Gramedia Pustaka Utama.

Kotler dan Keller, (2012). Marketing Management Edisi 14, Global Edition. Pearson Prentice Hall.

Kotler, Philip dan Gary Armstrong. (2001). Prinsip-Prinsip Pemasaran, jilid 2, edisi ke-8. Jakarta: Erlangga.

Kotler, Philip. (2002). Manajemen Pemasaran, Analisa
Perencanaan,Implementasi dan Kontrol. Edisi Kesembilan. Jilid 1. (Alih bahasa: Hendra Teguh S.E.,A.K., dan Ronny A. Rusli, S.E.). Jakarta: Prehalindo.

Kotler, Philip. (2005). Manajemen Pemasaran, Jilid 1 dan 2. Jakarta: PT. Indeks Kelompok Gramedia.

Kotler and Armstrong. (2006). Principles of Marketing, Eleventh Edition. New Jersey: Pearson Prentice Hall.

Kotler, Philip. (2008). Manajemen Pemasaran edisi kesebelas. Jilid 2, Edisi Bahasa Indonesia. Jakarta: Indeks.

Kotler, Philip; Armstrong, Gary, (2008). Prinsip-Prinsip Pemasaran, Jilid 1, Erlangga, Jakarta.

Lupiyoadi, Rambat. (2001). Manajemen Pemasaran Jasa. Jakarta: PT. Salemba Empat.

Mangkunegara, A.A. Anwar Prabu. (1988). Perilaku Konsumen. Bandung: Eresco.

Monroe, Allard C.R Van Riel et al. (2005). Marketing Antecedent of Industrial

Brand Equity: An Empirical Investigation in Specialty Chemical.

Mudrajat Kuncoro. (2003). Metode Riset untuk Bisnis dan Ekonomi. Jakarta: Erlangga.

Muhamad Ichsan, Maria Magdalena Minarsih dan Budi Hasiholan, Leonardo (2015). Effect Of Price, Features And Advertising On The Decision To Purchase Mobile Samsung Android (Study Case Against Samsung Android User Handphone In Regional District of Genuk). Universitas Pandanaran Semarang.

Peter, J. Paul dan Jerry C Olson. (2000). Consumer Behavior: Perilaku Konsumen dan Strategi Pemasaran. Jilid Satu. Edisi Keempat. Jakarta: Erlangga.

Sugiyono. (2013). Metodologi Penelitian Bisnis. Bandung: Alfabeta.

Sukotjo, Hendri dan Sumanto Radix A. (2010). Analisa Marketing Mix terhadap Keputusan Pembelian Produk Klinik Kecantikan Teta Surabaya.

Sumardi dan Silviana, Marlin dan Melone, Melina. (2011). Rest In Peace Advertising 1729-2010 A Mind And Soul Deceiver Lie Teller And Exaggeration Expert Killed By The Power Of World Of Mouth Marketing. Jakarta: PT. Gramedia Pustaka Utama.

Tjiptono, Fandy; Chandra, Gregorius; Adriana, Dadi. (2008). Pemsaran Strategik. Yogyakarta: Andi Offset. 